\author{
Mykola Yatskov, \\ Natalia Korchyk, \\ Oksana Mysina, \\ Nadia Budenkova
}

\title{
CREATION OF A COMBINED SYSTEM FOR TREATMENT OF IRON- CONTAINING WASTEWATER FROM ETCHING OPERATIONS
}

The object of research is the methods of purification of iron-containing wastewater from etching operations, the subject of the study is spent technological solutions of etching and wastewater from the operations of washing enterprises of hardware products. Spent etching solutions are characterized as highly concentrated solutions, and wash water belongs to the category of concentrated solutions containing toxic impurities: heavy metal ions, acids, surfactants. The main problem in the etching area is the processing of used etching solutions. The most progressive creation of combined systems in which the bulk of wastewater is treated in centralized systems with partial return of water to the production process. With such wastewater treatment, the problem arises of reducing the total concentration of iron to less than $1 \mathrm{mg} / \mathrm{l}$. That is why, in accordance with the requirements of environmental legislation on nature management, there is a need for deep additional treatment of such wastewater.

The study used the methods of potentiometric titration and chemical deposition, as well as the method of photometric determination. Magnetic cleaning was studied in an experimental magnetic deposition apparatus.

The paper presents the results of studies evaluating methods for purifying iron-containing wastewater from etching operations. Improvement is achieved by the creation of technological combined schemes for the purification of iron-containing wastewater, including a magnetic device as an auxiliary element. At the same time, the main volume of wastewater is treated in centralized systems with a partial return of water to the production process. Waste solutions from etching operations are subject to regeneration with return to the production process and partial dosage into the main wastewater stream from washing operations. Deep purification from iron-containing impurities using a magnetic device expands the possibilities of practical implementation of reverse osmosis to obtain «clean» water in centralized systems. This water is applicable for the preparation of process solutions and mixed with industrial water for flushing operations.

Keywords: combined schemes, treatment methods, wastewater, etching operations, ferrous impurities, magnetic device.

Yatskov, M., Korchyk, N., Mysina, O., Budenkova, N. (2021). Creation of a combined system for treatment of iron-containing wastewater from etching operations. Technology Audit and Production Reserves, 6 (3 (62)), 21-26. doi: http://doi.org/10.15587/2706-5448.2021.247550

\section{Introduction}

Etching of steel surfaces involves processing them with acid solutions $\left(\mathrm{HCl}, \mathrm{H}_{2} \mathrm{SO}_{4}\right)$ at an elevated temperature, resulting in the formation of liquid iron-containing waste wastewater (WW):

- spent etching solutions (SES), characterized as highly concentrated solutions;

- rinsing water (RW) belonging to the category of concentrated solutions.

The main problem of the etching site is the processing of high-pressure gas. In order to process them, local cycles of their neutralization, utilization, and regeneration are created [1, 2]. The most progressive creation of combined systems in which the bulk of wastewater is treated in centralized systems with partial return of water to the production process. SESs are subject to disposal [3] or regeneration [4] with partial return of chemical reagents to the production process and partially dosed into the WW stream from washing operations.

With such wastewater treatment, the problem arises of reducing the total iron concentration to less than $1 \mathrm{mg} / \mathrm{l}$. In practice, the WW treatment with an alkaline reagent, including milk of lime, is widespread, which makes it possible to provide the final total concentration of iron in WW up to $3 \mathrm{mg} / \mathrm{l}$. To ensure the concentration of iron in purified water less than $1 \mathrm{mg} / \mathrm{l}$, additional (deep) additional purification of water is required.

Since a significant part of iron-containing impurities are characterized by magnetically susceptible properties, the introduction of magnetic devices is promising for the purpose of deep purification of wastewater from such impurities. The main element of such devices is a granular filter media magnetized by an external device that generates 
a magnetic field. This direction has received intensive development, a thorough theoretical and experimental base of the deposition process has been developed, and a number of effective designs of magnetic filtration devices have been created [5].

The paper considers the use of a magnetic device for the purpose of deep additional purification of wastewater from iron-containing impurities. The magnetic device contains a cylindrical body with a filter nozzle, a solenoid, and a system of electrodes located in it. In this case, the filtering nozzle is made of a cellular ferroelectric, and the inner surface of the device body contains an insulating coating of an electrically non-conductive material. The filtering attachment can also be made of metallized barium titanate, and the insulating coating of the inner surface of the body is made of fluoroplastic [6].

\section{The object of research and its technological audit}

The object of research is the methods of purification of iron-containing wastewater from etching operations, the subject of research is spent technological solutions of etching and wastewater from the operations of washing enterprises of metalware products. The study was carried out on waste technological solutions and washing water for etching of steels of the enterprise «Plant of Metalware Products» (Kyiv, Ukraine) in laboratory and experimental-industrial conditions.

Among the numerous methods for WW treatment, including the removal of iron-containing impurities, the reagent method is the most widespread. However, the purified water is characterized by a high salt content. As a result of reagent treatment, tens of thousands of tons of iron-containing sludge are formed, the bulk of which is not subject to further processing (disposal). Spent etching solutions are characterized as highly concentrated solutions, and wash water belongs to the category of concentrated solutions containing toxic impurities: heavy metal ions, acids, surfactants. That is why, in accordance with the requirements of environmental legislation on nature management, there is a need for deep additional treatment of such wastewater.

\section{The aim and objectives of research}

The aim of research is to search for methods of improving the technological scheme of purification of iron-containing wastewater from etching operations by creating combined systems, including reagent purification of wastewater, their mutual neutralization, regeneration of etching solutions, deep additional purification using a magnetic device.

To achieve the set aim, it is necessary to solve the following objectives:

1. To conduct research and evaluate different reagent methods for purification of concentrated wastewater from the etching of metals.

2. To investigate the possibility of using a magnetic device for deep post-treatment of iron-containing wastewater.

\section{Research of existing solutions to the problem}

Among the numerous methods for WW treatment, including from iron-containing impurities - reagent, ion-exchange, sorption, membrane, biochemical, electrochemical - the most common is the reagent method [7-9]. In the WW reagent treatment from iron-containing impurities, sodium hydroxide and carbonate are used as an alkaline reagent, as well as cheaper calcium hydroxide (lime, milk of lime) [10]. For example, annually at the enterprises of Ukraine, as a result of the reagent cleaning process, 10.0-12.5 thousand tons of iron-containing sludge (sediment) are formed, the bulk of which cannot be further processed.

Sorption purification methods - adsorption and ion exchange $[11,12]$ are quite common, but their limitations in industrial use are associated with the complication of the regeneration and reuse of the sorbent and eluates.

The well-known methods of additional WW treatment reverse osmosis and ultrafiltration [13] - provide a sufficiently high degree of additional purification, allow to return purified water to production and regenerate dissolved substances. At the same time, the power consumption is quite insignificant. Reverse osmosis and ultrafiltration plants are compact and easy to operate. However, over time, trapped substances accumulate on the surface of the membranes, as a result of which their permeability and selectivity decreases. Low chemical resistance in aggressive media and high cost of membranes limit the use of membrane methods for the purification of wastewater from the etching area from iron-containing impurities [14].

Magnetic treatment refers to the physical factors affecting the components of the water system [15]. In all cases, the effect of a magnetic field on a water system leads to a change in the physical properties of water structure, its density, surface tension, etc., which can lead to phase-dispersed transformations. In practice, the most common technologies include the influence of a magnetic field as a factor in intensifying reagent cleaning: coagulation, oxidation, reduction, settling, etc.

The intensification of the phase formation-dissolution transition is due to the physical effect on the formation of the spatial structures of the water system. A device for magnetic-electric activation of reagent solutions is known, which provides for the effect of a magnetic field on the initial solution and subsequent electrocoagulation. Industrial tests have shown a fairly high improvement in water transparency: the content of suspended particles decreased by $28.6-60.5 \%$, color - by $32.5-50.0 \%$, the consumption of coagulant decreased by $15.0-22.0 \%$ [12].

Scientists associate the influence of a magnetic field on the transformation between molecules and ions (molarization $\leftrightarrow$ ionization) with the phenomena of ion hydration $[16,17]$. In this case, ionic associates arising under the influence of a magnetic field are embryos of the solid phase and play the role of crystallization centers. The effect of magnetic treatment on the concentration of dissolved gases, primarily oxygen and carbon dioxide, manifests itself in proton-electron changes in the water system (Fig. 1).

This phenomenon has an effective meaning in the purification of wastewater by destructive methods; water softening systems [15] and saline water utilization. It has been shown that after magnetic treatment the boiling point of water decreases by several degrees and the heat of its evaporation decreases, which leads to significant savings in energy resources [12].

Let's believe that the use of magnetic and magneticelectric wastewater treatment for the extraction (separation) of iron-containing impurities as an element of auxiliary systems providing deep (additional treatment) of wastewater is more promising. 


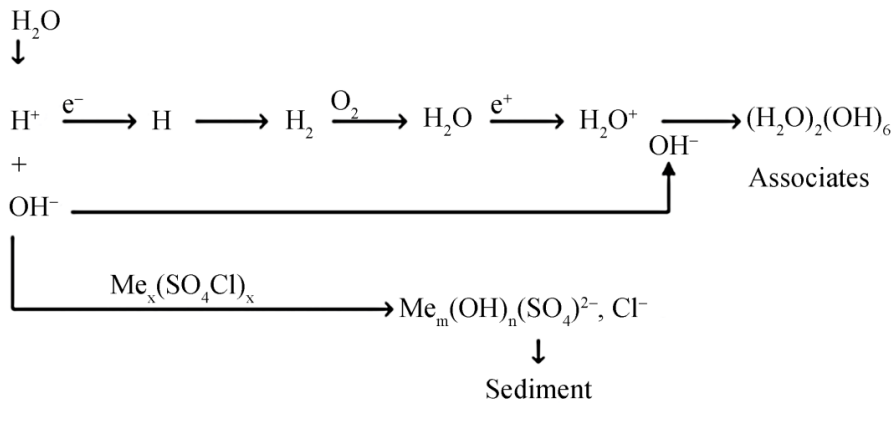

Fig. 1. Scheme of changing the state of the water system

The results of studies of the technology of magneticelectric wastewater treatment, carried out earlier, made it possible to develop a device that creates a high-gradient electric field in the working zone of deposition in combination with a branched filtering surface. This increases the forceful effect on electrically charged impurities, especially particles with a low specific electric charge. As a result, the proposed device provides an increase in the overall efficiency and degree of purification of fluid technological media, including wastewater [6]. In this technological solution, let's propose to implement deep purification of wastewater from the etching area from iron-containing impurities using a magnetic device, followed by desalination by reverse osmosis.

\section{Methods of research}

To study the acid-base and redox properties of wastewater and treatment conditions for the purpose of purification, utilization, regeneration, methods of potentiometric titration and chemical precipitation in a batch reactor with intensive stirring of reagents were used.

Quantitative analyzes for the content of iron ions were carried out in laboratory conditions by the method of photometric determination with sulfosalicylic acid. Potentiometric titration was carried out in laboratory conditions on an EV 74 potentiometer (Belarus) and in industrial research conditions using a portable $\mathrm{pH}$ meter $\ll \mathrm{pH}$ 602» (Ukraine). Magnetic wastewater treatment was studied in an experimental magnetic deposition device.

The device consists of a tubular working body made of stainless non-ferromagnetic steel with an inner diameter of $25 \mathrm{~mm}$, filled with a ferromagnetic filtering nozzle in the form of granules of steel shavings with an equivalent diameter of $2-4 \mathrm{~mm}$. The magnetic field was created using a sectional solenoid, to which a direct current was applied. The magnetizing system was placed around the working body. The sectional solenoid was formed from separate coils connected in series to ensure the changeable working length (height) of the nozzle. The solenoid was electrically powered by direct current, with a range of variability in the magnitude of the magnetizing field $H$ in the range from 30 to $120 \mathrm{kA} / \mathrm{m}$. Wastewater containing ferrous impurities for the experiments was taken into special stainless steel containers. In the experimental setup, the capacity of the pure product was also assumed. At the inlet and outlet of the installation, samplers were installed for analyzing samples and determining the degree of purification of aqueous media from impurities in a magnetized filtering attachment when changing the length (height) of the attachment layer $(L)$, external magnetic field strength $(H)$, filtration rate $\left(V_{f}\right)$ [18].
The degree of purification was calculated from the relative change in the content (concentration) of iron-containing impurities in terms of the total iron content before deposition in the packing and after deposition according to the formula:

$$
\psi=\frac{C_{0}-C}{C_{0}},
$$

where $C_{0}$ - the iron concentration at the inlet of the magnetic filter; $C$ - the value of the iron concentration after sedimentation, which corresponds to certain values of $L, H$ and $V_{f}$.

\section{Research results}

6.1. Research results of wastewater treatment methods using a magnetic device. Research has been carried out to study the effect of the length (height) of the packing layer $L$, the magnetic field strength $H$, and the filtration rate $V_{f}$ using model magnetite suspensions in an experimental setup including a granular (granular) filtering load magnetized by an external device.

As a result of the studies carried out, it was found that the highest degree of purification of aqueous media $\psi$ is observed (Fig. 2) in the following ranges of the main technological parameters of magnetic deposition: $H$ - up to $50-60 \mathrm{kA} / \mathrm{m}, V_{f}-$ up to $100-150 \mathrm{~m} / \mathrm{h}, L-$ up to $0.6-0.8 \mathrm{~m}$.

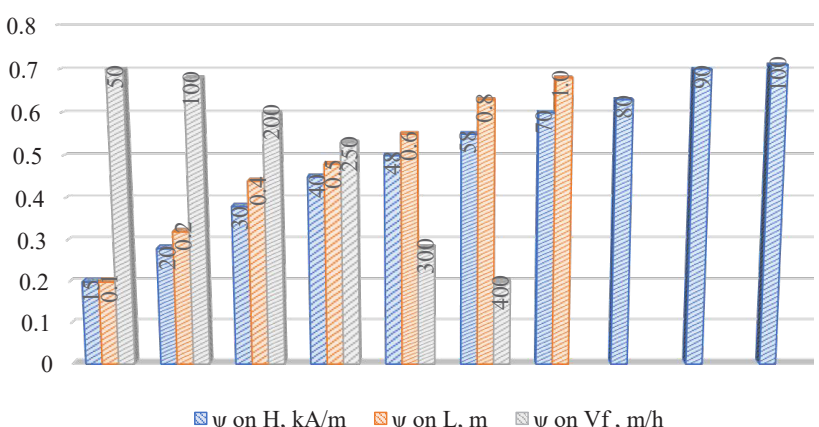

Fig. 2. Influence of the length (height) of the packing layer $L$ magnetic field strength $H$, filtration rate $V_{f}$ on the degree of wastewater treatment $\psi$

The disadvantage of the known magnetic devices for cleaning, containing granular loading, is the low force effect on the impurities separated (extracted) from the wastewater. A patented design of a magnetic device allows separation of magnetic and non-magnetic impurities of wastewater due to the fact that a high-gradient electric field is generated in the working area of the device in combination with a branched magnetic surface of the filter media [6]. This increases the force effect on the impurities of wastewater to be separated (especially with a low specific electric charge), and as a result, the degree of wastewater treatment increases.

At the same time, the magnetic device provides for the separation of wastewater impurities into ferromagnetic and non-ferromagnetic fractions by acting on the magnetized medium created by the solenoid.

The predicted degree of purification of iron-containing wastewater, depending on the strength of the external magnetic field at a filtration rate of $100 \mathrm{~m} / \mathrm{h}$ and $L=0.8 \mathrm{~m}$, is $0.6-0.7$. Let's assume that the particle size of impurities is in the range from 2 to 4 microns. 
As a result of the study, a technological solution has been proposed, which consists in the fact that a magnetic device is used as an auxiliary element in technological systems for purifying wastewater from a section of the etching section. Wastewater after reagent cleaning with the addition of a coagulant, flocculant, alkaline reagent and after a polystyrene foam filter is fed to a magnetic filter with granular loading. The results of studies of wastewater treatment from the etching site (sulfate-chloride solution) are given in Table 1.

Table 1

Indicators of wastewater treatment from the etching site (sulfate-chloride solution)

\begin{tabular}{|c|c|c|c|}
\hline $\begin{array}{c}\text { Volume 40 \% } \\
\mathrm{NaOH}, \mathrm{l} / \mathrm{m}^{3}\end{array}$ & $\mathrm{pH}$ & $\begin{array}{c}\text { Iron concentration } \\
\text { after reagent clean- } \\
\text { ing, } \mathrm{g} / \mathrm{l}\end{array}$ & $\begin{array}{c}\text { Iron concentration after } \\
\text { magnetic device with } \\
\psi=0.7 \mathrm{~g} / \mathrm{l}\end{array}$ \\
\hline 0 & 0.7 & 2.5 & - \\
\hline 50 & 1 & - & - \\
\hline 100 & 1.8 & $0.32 \cdot 10^{-3}$ & $0.096 \cdot 10^{-3}$ \\
\hline 200 & 2 & $0.24 \cdot 10^{-3}$ & $0.072 \cdot 10^{-3}$ \\
\hline 250 & 2.6 & $0.12 \cdot 10^{-3}$ & $0.036 \cdot 10^{-3}$ \\
\hline 450 & 12 & $0.12 \cdot 10^{-3}$ & $0.036 \cdot 10^{-3}$ \\
\hline
\end{tabular}

Thus, the use of an electromagnetic device (filter) will provide deep purification of wastewater from iron ions, which is very important for further desalination by reverse osmosis [1]. The proposed technical solution allows to solve the problem of returning wash water to production processes. RW regeneration is the most difficult problem for sulphate etching.

6.2. Improvement of the technological scheme for the purification of iron-containing wastewater from etching operations. For the purpose of improvement, the surface preparation section includes the following operations: degreasing, two-stage rinsing (hot and cold), after degreasing, etching, cold rinsing after etching [19, 20].

In order to reduce the consumption of chemical reagents and ensure effective subsequent neutralization of toxic waste, let's recommend to include additional technological equipment for local cycles of purification of technological solutions and wastewater from washing operations, providing:

- regeneration of solutions from etching operations

(the total volume of regeneration is up to $50 \%$ );

- mutual neutralization of solutions from etching and degreasing operations (total volume up to $50 \%$ ).

In order to ensure deep wastewater treatment, it is recommended to use additional equipment, namely a magnetic device that provides electromagnetic separation of wastewater impurities.

Regeneration of solutions from etching operations is carried out by the method of treatment with an alkaline reagent and hydrogen peroxide in an acidic medium in order to precipitate iron ions in the form of hydroxo compounds, followed by separation on a vacuum filter with a chemical cloth. Hydrogen peroxide promotes the formation of iron (III) hydroxo complexes, which are capable of forming insoluble compounds in an acidic medium. It is recommended to use a $10-20 \% \mathrm{NaOH}$ solution as an alkaline reagent. It should be noted that the use of milk of lime has a negative effect on the surface of the metal to be etched.
The use of hydrogen peroxide makes it possible to increase the effect of iron extraction from etching solutions by $30 \%$ (the overall purification effect is $70 \%$ ) under the same conditions at an alkaline reagent consumption of $1.5 \mathrm{~mol} \mathrm{NaOH}$ per $1 \mathrm{~mol} \mathrm{Fe}^{2+}$. The clarified solution to restore the etching ability is enhanced with concentrated $\mathrm{HCl}$ in a 1:1 ratio. As a result of the proposed technological solutions, the consumption of commercial $\mathrm{HCl}$ is reduced by $50 \%$. In experimental industrial conditions, the costs of reagents, their concentration, and the dosage time (Fig. 3) have been established, which ensures the extraction of the sludge of hydroxo compounds of the iron of a stable composition for its subsequent utilization (processing).

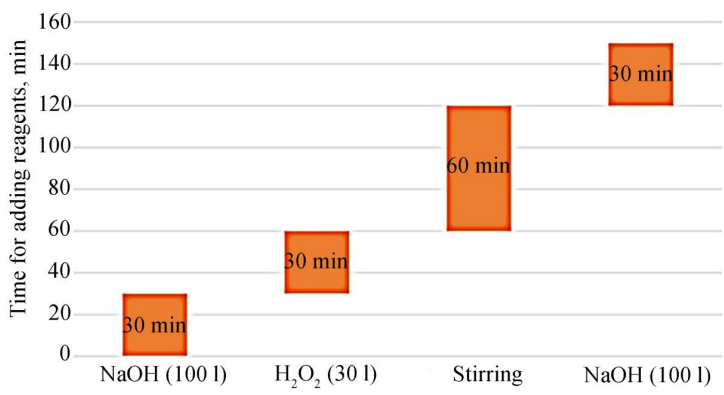

Fig. 3. The sequence of adding reagents for the regeneration of the spent etching solution: $\mathrm{NaOH}-20 \%$ per $1 \mathrm{~m}^{3} ; \mathrm{H}_{2} \mathrm{O}_{2}-20 \%$ per $1 \mathrm{~m}^{3}$

Approximately a third of the illuminated solution $\left(0.7 \mathrm{~m}^{3}\right.$ of the illuminated filtrate is formed from $1 \mathrm{~m}^{3}$ of SES, of which $0.5 \mathrm{~m}^{3}$ is returned to the technological process, and $0.2 \mathrm{~m}^{3}$ - for mutual neutralization) is sent to the local cycle of mutual neutralization with the process solution from operations degreasing. The presence of residual concentrations of iron ions and hydrogen peroxide in an alkaline medium provides conditions for the coagulation of surfactants and oils entering the process solution during defatting [21].

For subsequent purification, wastewater generated in local cycles is fed to the structures of centralized purification systems.

The main purpose of wastewater treatment ( $80 \%$ from washing operations and $20 \%$ from local cleaning cycles) is to extract iron ions in the form of insoluble hydroxo compounds, which is achieved by dosage of an alkaline reagent ( $\mathrm{NaOH}$ solution with a concentration of $1 \%$ ). At the same time, to accelerate the formation phase (of insoluble hydroxo compounds), a dosage of a flocculant is recommended. The practical implementation of this process at one of the enterprises of Ukraine made it possible to make recommendations for improving the cleaning technology, namely:

- the dosage of the alkaline reagent and flocculant can be carried out in one apparatus of the reactormixer-settler type;

- the subsequent separation of the formed suspension is carried out on a polystyrene foam filter, which provides additional cleaning from iron ions in the thickness of the filter media and effective separation of suspended solids; - for deep cleaning of iron ions (Table 2), let's recommend using a magnetic device [6]. The use of this device increases the overall cleaning efficiency by additional formation of the solid phase of salts, which determine the hardness in the volume of wastewater when it passes through the system of magnets; 
- after separation of the additionally formed suspension of salts (sedimentation - filtration), it is recommended to supply part of the flow to the reverse osmosis unit.

Table 2

Indicators of purification of iron-containing wastewater from etching operations

\begin{tabular}{|c|c|c|c|c|}
\hline Indicator name & $\begin{array}{c}\text { Unit of } \\
\text { measure- } \\
\text { ment }\end{array}$ & $\begin{array}{c}\text { Before } \\
\text { treatment }\end{array}$ & $\begin{array}{c}\text { After } \\
\text { treatment }\end{array}$ & $\begin{array}{c}\text { Maximum permis- } \\
\text { sible concentration } \\
\text { of industrial water } \\
\text { category II [1] }\end{array}$ \\
\hline $\mathrm{pH}$ & unit & $5 \div 6$ & $7 \div 8$ & $6 \div 9$ \\
\hline Iron, $\mathrm{Fe}^{2+}$ & $\mathrm{mg} / 1$ & 600 & 0.096 & 0.3 \\
\hline Chlorides, $\mathrm{Cl}^{-}$ & $\mathrm{mg} / 1$ & 627 & 98 & 100.0 \\
\hline Sulphates, $50_{4}^{2-}$ & $\mathrm{mg} / 1$ & 220 & 69.1 & 150.0 \\
\hline Magnesium, $\mathrm{Mg}^{2+}$ & $\mathrm{mg} / 1$ & 26.75 & 1.8 & 3.0 \\
\hline Hardness & $\mathrm{mg}-\mathrm{eq} / 1$ & 10 & 0.8 & 2.0 \\
\hline
\end{tabular}

Thus, deep cleaning from iron-containing impurities using a magnetic device is provided. At the same time, the possibilities for the practical implementation of reverse osmosis for obtaining pure water are expanding. Such water is applicable for the preparation of technological solutions and, in a mixture with industrial water, for flushing operations.

\section{SWOT analysis of research results}

Strengths. The strengths of this study are that it provides deep cleaning from ferrous impurities using a magnetic device. This expands the possibilities for the practical implementation of reverse osmosis. This allows to obtain clean water, which is applicable for the preparation of technological solutions and mixed with industrial water for washing operations. The proposed technological solution is the result of research carried out that meets the conditions for creating a new technique (technology).

Weaknesses. The weaknesses of this study are related to the fact that the proposed technological scheme for the purification and additional purification of iron-containing wastewater is multistage and requires the use of equipment.

Opportunities. Subsequent research should focus on:

- expansion of the concentration of salt content of wastewater, which can be regenerated according to the above technology;

- reduction of the number of stages in the technological scheme of purification and deep additional purification of iron-containing wastewater;

- reduction of the share of the use of high-cost equipment.

Threats. It is more expedient to organize centralized sections or specially organized stations for the SES processing, including etching solutions from different enterprises Currently, local cycles of processing of spent herbal solutions, including solutions of the etching tract, have been introduced, limited by economic organizational and other factors of an individual enterprise.

\section{Conclusions}

1. It has been shown that the regeneration of solutions from etching operations is carried out by the method of treatment with an alkaline reagent and hydrogen peroxide in an acid-oxide medium in order to precipitate iron ions in the form of hydroxo compounds with subsequent separation on a vacuum filter with a chemical cloth. The use of hydrogen peroxide makes it possible to increase the effect of iron extraction from etching solutions by $30 \%$ (the overall purification effect is $70 \%$ ) under the same conditions at an alkaline reagent consumption of $1.5 \mathrm{~mol} \mathrm{NaOH}$ per $1 \mathrm{~mol} \mathrm{Fe}^{2+}$. To reduce the consumption of chemical reagents and ensure effective subsequent neutralization of toxic waste, let's recommend that for the surface preparation site include additional technological equipment for local cycles of cleaning process solutions and wastewater from flushing operations. This will allow to:

- regeneration of solutions from etching operations

(the total volume of regeneration is up to $50 \%$ );

- mutual neutralization of solutions from etching and degreasing operations (total volume up to $50 \%$ ). As a result of the proposed technical solutions, the consumption of commercial $\mathrm{HCl}$ is reduced by $50 \%$. In experimental industrial conditions, the costs of reagents, their concentration, and the dosage time have been established, which ensures the extraction of the sludge of hydroxo compounds of the iron of a stable composition for its subsequent utilization (processing).

2. To improve the technological scheme of wastewater treatment from etching operations from ferrous impurities in combined systems, it is recommended to use a magnetic device, in which a granular filter media is used as the main element, which is magnetized by an external device that generates a magnetic field. The use of a magnetic device will provide deep purification of wastewater from iron ions. This is very important for further desalination by reverse osmosis and allows to solve the problem of returning wash water to production processes, which is the most difficult for sulphate etching.

\section{References}

1. Yatskov, M., Korchyk, N., Budenkova, N., Kyrylyuk, S., Prorok, O. (2017). Development of technology for recycling the liquid iron-containing wastes of steel surface etching. EasternEuropean Journal of Enterprise Technologies, 2 (6 (86)), 70-77. doi: https://doi.org/10.15587/1729-4061.2017.97256

2. Denzanov, H. O., Petruk, V. Kh., Tkhor, I. I. (2008). Pat. No. 35548 UA. Sposib reheneratsii i vykorystannia vidpratsovanykh traoylnykh rozchyniv. MKP: C01G 3/00. No. u200804873; declareted: 15.04.2008; published: 25.09.2008, Bul. No. 18, 10. Available at: https://uapatents.com/2-35548-sposib-regeneracii-utilizaci-vidpracovanikh-travilnikh-rozchiniv.html

3. Vasylenko, I. A., Kumanov, S. O. (2013). Pat. No. 102154 UA. Sposib utylizatsii kyslykh zalizovmisnykh rozchyniv. MKP: $\mathrm{C} 02 \mathrm{~F}$ 1/64, C01G 49/02, C09C 1/22, C09C 1/24. No. a201112825; declareted: 01.11.2011; published: 10.06.2013, Bul. No. 11, 6 . Available at: https://uapatents.com/5-102154-sposib-utilizacikislikh-zalizovmisnikh-rozchiniv.html

4. Diumaev, K. M., Elbert, E. I., Suschev, V. S., Perfilev, V. M. (1987). Regeneratsiia otrabotannykh sernokislotnykh rastvorov. Moscow: Khimiia, 112.

5. Sanduliak, A. V. (1988). Magnitno-filtratsionnaia ochistka zhidkostei $i$ gazov. Moscow: Khimiia, 136.

6. Yatskov, M. V., Mysina, O. I. (2001). Pat. No. 36351 A UA. Prystrii dlia ochyshchennia ridyny vid mahnitnykh ta nemahnitnykh vkliuchen. MPK: V03S 1/30, V01D 35/06. No. 99126648; declareted: 07.12.1999; published: 16.04.2001, Bul. No. 3, 3. Available at: https://uapatents.com/3-36351-pristrijj-dlya-ochishhennyaridini-vid-magnitnikh-ta-nemagnitnikh-vklyuchen.html

7. Yavorskyi, V. T., Kuntyi, O. I., Kozak, S. I., Sribnyi, V. M. (1999). Elektrokhimichne oderzhannia metaliv u vodnykh rozchynakh. Lviv: DU «LP», 118. 
8. Zapolskyi, A. K. (2005). Fizyko-khimichni osnovy tekhnolohii ochyshchennia stichnykh vod. Kyiv: Vyshcha shkola, 671.

9. Kochetov, G. M. (2000). Kompleksnaia ochistka stochnykh vod promyshlennykh predpriiatii s regeneratsiei tiazhelykh metallov. Ekotekhnologii i resursosberezhenie, 4, 41-43.

10. Filipchuk, V. L. (2004). Ochyshchennia bahatokomponentnykh metalovmishchuiuchykh stichnykh vod promyslovykh pidpryiemsto. Rivne: UDUVHP, 8-11.

11. Uretskii, E. A. (2007). Resursosberegaiuschie tekhnologii v vodnom khoziaistve promyshlennykh predpriiatii. Brest: BrGTU, 396.

12. Nester, A. A., Korchik, N. M., Baran, B. A. (2008). Stichni vodi pidpriiemsto ta iykh ochischennia, 171.

13. Kalinovskii, E. A., Saranin, O. L. (1999). Bezotkhodnye tekhnologii ochistki stochnykh vod. Ochistka galvanicheskikh stokov. Ekotekhnologii $i$ resursosberezhenie, 1, 48-53.

14. Cherkasov, A. N., Pasechnik, V. A. (1991). Membrany $i$ sorbenty v biotekhnologii. Leningrad: Khimiia, 240.

15. Dushkin, S. S. (1985). Intensifikatsiia protsessov ochistki vody magnito-elektricheskoi aktivatsiei rastvora koagulianta. Stroitelstvo i arkhitektura, 6, 105-107.

16. Dushkin, S. S., Beliaev, V. I. (1982). Issledovanie magnitnoi aktivatsii ionitov pri korrektirovke solevogo sostava stochnykh vod. Izvestiia vuzov. Stroitelstvo i arkhitektura, 8, 112-117.

17. Shaposhnik, V. A. (2003). Kineticheskaia teoriia vodnykh rastvorov elektrolitov. Vesnik VGU. Seriia Khimiia. Biologiia. Farmatsiia, 2, 81-85.

18. Sanduliak, A. V., Garaschenko, V. I. (1982). Elektromagnitnye filtr-osaditeli. Lviv: Vischa shkola, 72.

19. Shluger, M. A. (Ed.). (1985). Galvanicheskie pokrytiia v mashinostroenii. Vol. 1. Moscow: Mashinostroenie, 240.

20. Vinogradov, S. S. (2005). Organizatsiia galvanicheskogo proizvodstva. Oborudovanie, raschet proizvodstva, normirovanie. Moscow: Globus, 256
21. Korchyk, N. M., Yatskov, M. V., Bielikova, S. V. (2012). Pat. No. 76053 UA. Sposib ochyshchennia stichnykh vod halvanichnoho vyrobnytstva. MPK: S02F 9/04. No. u201206086; declareted: 21.05.2012; published: 25.12.2012, Bul. No. 24, 4. Available at: https://uapatents.com/6-76053-sposib-ochishhennya-stichnikhvod-galvanichnogo-virobnictva.html

Mykola Yatskov, PhD, Senior Researcher, Professor, Department of Chemistry and Physics, National University of Water and Environmental Engineering; Director of Rivne Technical Professional College of National University of Water and Environmental Engineering, Rivne, Ukraine, ORCID: https://orcid.org/0000-0002-6231-6583

Natalia Korchyk, PhD, Associate Professor, Department of Chemistry and Physics, National University of Water and Environmental Engineering, Rione, Ukraine, ORCID: https://orcid.org/0000-00034919-6510

$\triangle$ Oksana Mysina, Senior Lecturer, Department of Chemistry and Physics, National University of Water and Environmental Engineering, Rivne, Ukraine, e-mail: o.i.mysina@nuwm.edu.ua, ORCID: https:// orcid.org/0000-0003-2556-0947

Nadia Budenkova, PhD, Associate Professor, Department of Chemistry and Physics, National University of Water and Environmental Engineering, Rivne, Ukraine, ORCID: https://orcid.org/0000-00032176-3405

$\triangle$ Corresponding author 